\title{
Effect of Plant Age and Saline Water on Antioxidant and Peroxidase Activity in Sweet Pepper Fruit
}

\author{
Ana Serrano-Martínez ${ }^{1}$, Francisco del Amor ${ }^{2}$, Maria Isabel Fortea ${ }^{3}$, Carmen Lucas-Abellán ${ }^{1}$, \\ Santiago López-Miranda ${ }^{1} \&$ Estrella Núñez-Delicado ${ }^{1}$ \\ ${ }^{1}$ Department of Nutrition and Food Technology, Universidad Católica San Antonio de Murcia, Murcia, Spain \\ ${ }^{2}$ Department of Agriculture of AC Murcia, IMIDA, Murcia, Spain \\ ${ }^{3}$ Department of Nursing, Universidad Católica San Antonio de Murcia, Murcia, Spain \\ Correspondence: Estrella Núñez Delicado, Department of Nutrition and Food Technology, Universidad Católica \\ San Antonio de Murcia, Spain. Tel: 34-968-278-869. E-mail: enunez@ucam.edu
}

\author{
Received: July 22, 2014 Accepted: August 11, 2014 Online Published: November 15, 2014 \\ doi:10.5539/jas.v6n12p139 URL: http://dx.doi.org/10.5539/jas.v6n12p139
}

\begin{abstract}
Sweet pepper (Capsicum annum L.) fruits are an excellent source of bioactive products but the content of the same is related with the plant response to stressful conditions. Salinity is among the major constrains restricting to growth and development of plants, and optimizing irrigation strategies could improve fruit quality while saving good quality water.

Mature fruits from plants grown at two saline concentrations (20 and $40 \mathrm{mM} \mathrm{NaCl}$ ), beginning 50, 100 and 150 days after transplanting and a control $(0 \mathrm{mM} \mathrm{NaCl})$ were studied. Vitamin $\mathrm{C}$ levels fell as the salt concentration in the irrigation increased, while total phenolic compounds and POD activity rose. Additionally, early harvested fruits (young plants) produced fruits with higher concentration of vitamin $\mathrm{C}$ than those harvested later, but total phenolic compounds and POD activity showed the opposite behaviour. Marketable yield was also affected by the moment of salinization. Thus, the late the saline stress was imposed, the more attenuated was the effect on the studied parameters.

The intensity of fruit response to salinity was significantly modulated by the age of the plant. Therefore, in addition to the level and duration of saline stress imposed, plant age should also be considered when determining the optimum irrigation strategy.
\end{abstract}

Keywords: antioxidant activity, peroxidase, phenolic compounds, ascorbic acid, saline stress

\section{Introduction}

Pepper is an important agricultural crop, not only because of its economic importance, but also for the nutritional value of its fruits. They are an excellent source of natural colours and antioxidant compounds (Howard, Talcott, Brenes, \& Villalon, 2000), the intake of which is regarded as an important health-protecting factor. Pepper consumption has been recognized as contributing to the prevention of a multitude of human diseases, including cancer and cardiovascular diseases when taken daily in adequate amounts (Bramley, 2000).

A wide spectrum of antioxidant compounds is found in pepper fruits, the most important being vitamin C. It is known that vitamin C chelates heavy metal ions (Namiki, 1990), reacts with singlet oxygen and other free radicals, and suppresses peroxidation, reducing the risk of arteriosclerosis, cardiovascular diseases, and some forms of cancer (Harris, 1996). Phenolic compounds are secondary metabolites in plants. These compounds have an aromatic ring with one or more hydroxyl moieties. They retard or inhibit lipid autoxidation by acting as radical scavengers and, consequently, are essential antioxidants that protect against propagation of the oxidative chain (Namiki, 1990). The most important phenolic compounds in pepper are flavonoids, anthocyanins and flavonols. Flavonoids are involved in the organoleptic properties of fruit and vegetables, such as taste (Tomás-Barberán \& Espín, 2001), while anthocyanins are natural pigments, responsible for the colour of most fruits, flowers and leaves, and flavonols, which are induced by sunlight, attenuate the effect of ultraviolet rays in the plant (Price, Breen, Valladao, \& Watson, 1995).

Related with the oxidation of phenolic compounds are the oxidative enzymes. Peroxidase (POD; EC 1.11.1.7) is 
an oxydoreductase enzyme involved in enzymatic browning, while diphenols act as reducing substrates in the enzymatic reaction (Robinson, 1991). The involvement of POD in browning processes has been reported by many researchers (Richard-Forget \& Gauillard, 1997), although this effect is limited by the availability of electron acceptor compounds such as superoxide radicals, hydrogen peroxide, and lipid peroxides. The oxidation of a wide range of organic compounds by POD has led to speculation that this enzyme may be associated with losses in colour, flavour and nutritional values in raw and processed foods (Serrano-Martínez, Fortea, Del Amor, \& Núñez-Delicado, 2008).

Intensive cultivation of greenhouse-grown sweet peppers can achieve yields more than four times those attained in open-field production, and the high quality of fruit produced and off-season harvesting allow wholesale prices to be 3 to 5 times greater than for field-grown fruits (Jovicich, Cantliff, Sargent, \& Osborne, 2004). In soilless greenhouse cultivation, crop response is also affected by the different substrates in which plants are grown and, in some cases when the water quality is poor, by salt stress. The exact effect of salt stress depends on the plant age and on the duration (del Amor 2001; del Amor \& Gómez-López, 2009; Morales-García, Stewart, Seguin, \& Madramootoo, 2011). Nowadays, more than $6 \%$ of the world's land area is salt affected, most as a result of natural causes and the accumulation of salts ver long periods of time in arid and semiarid zones (Rengasamy, 2002). Pepper plants are often cultivated in regions where irrigation water is limited and contains high $\mathrm{NaCl}$ concentrations. Salinity decreases pepper yield (Navarro, Garrido, Carvajal, \& Martínez, 2002), a response that is also affected by the variety considered. Plants exposed to harmful stress conditions produce cytotoxic reactive oxygen species that can seriously disrupt the normal metabolism through the oxidative damage of lipids, proteins and nucleic acids. In order to defend themselves against oxidants, plants have developed specific protective mechanisms, involving antioxidant molecules and enzymes. Plants with high levels of antioxidants, whether constitutive or induced, have been reported as having greater resistance to such oxidative damage (Foyer, 1993).

Among other damage, the use of saline waters for irrigation causes damage in plants such us toxicity and oxidative stress (Zhu, 2002). These factors, separately or combined, have adverse effects on plant development, at different levels: molecular (Zhu, 2002), biochemical (Parida \& Das, 2005), physiological (Munns, 2002) and whole plant (Munns \& Termaat, 1986).

In general, the physicochemical parameters of fruits, their flavour and nutritional properties are affected by the salinity of the irrigation water used. This inevitably affects the final quality of horticultural products (Navarro, Flores, Garrido, \& Martínez, 2006). In this paper, we study the effect of the salt concentration and the time of the application (plant age) on several quality parameters of pepper fruits (total phenolics, ascorbic acid, antioxidant activity and POD activity).

\section{Materials and Methods}

\subsection{Sampling and Salinity Treatment}

Sweet pepper plants (Capsicum annuum L. type Lamuyo, cv Herminio), obtained from a commercial nursery were transplanted on December 28, and grown in a greenhouse equipped with a computer-regulated drip irrigation system under controlled environmental conditions.

Three plants were placed in each bag of soilless substrate (coconut fiber, brand Cocopeat ${ }^{\circledR}$ ). Each substrate bag was irrigated with three pressure compensated, anti-drain drip emitters with a $4 \mathrm{~L} / \mathrm{h}$ flow. Plants were irrigated according to the demand detected in the appropriate trays. Two bags of coconut fiber for each treatment were placed on a demand tray, which had two electrodes for controlling the level of the solution. When plants transpired, the water level dropped, which was detected by the electrodes thus initiating irrigation. The irrigation stopped when the level of water in the tray returned to the initial level. Additionally, a surplus of $30 \%$ of the plant water uptake was applied the plants to avoid nutrient imbalance and/or excessive salinity in the rhizosphere (Del Amor, Martínez, \& Cerdá, 1999). The greenhouse has three irrigation sectors, in which 0, 20 or $40 \mathrm{mM}$ of $\mathrm{NaCl}$ (S1, S2 and S3) were added to the standard nutrient solution used by local pepper growers. The application of the resulting nutrient solutions began 50, 100 or 150 days after transplanting (DAT), according to the pattern described in Figure 1. This pattern of $\mathrm{NaCl}$ application meant a total of 7 treatments (T1-T7). Pepper fruits were harvested in their mature green-colour stage on April 11 (early harvest), June 6 (intermediate harvest), and July 25 (late harvest). The greenhouse had 11 lines of plants with 24 bags (containing the substrate) each. Each treatment had four blocks with three substrate bags, containing three plants per bag. The design was fully-randomized block. Four fruits per block were harvested for each treatment and at each harvest time (early, intermediate or late harvest). 


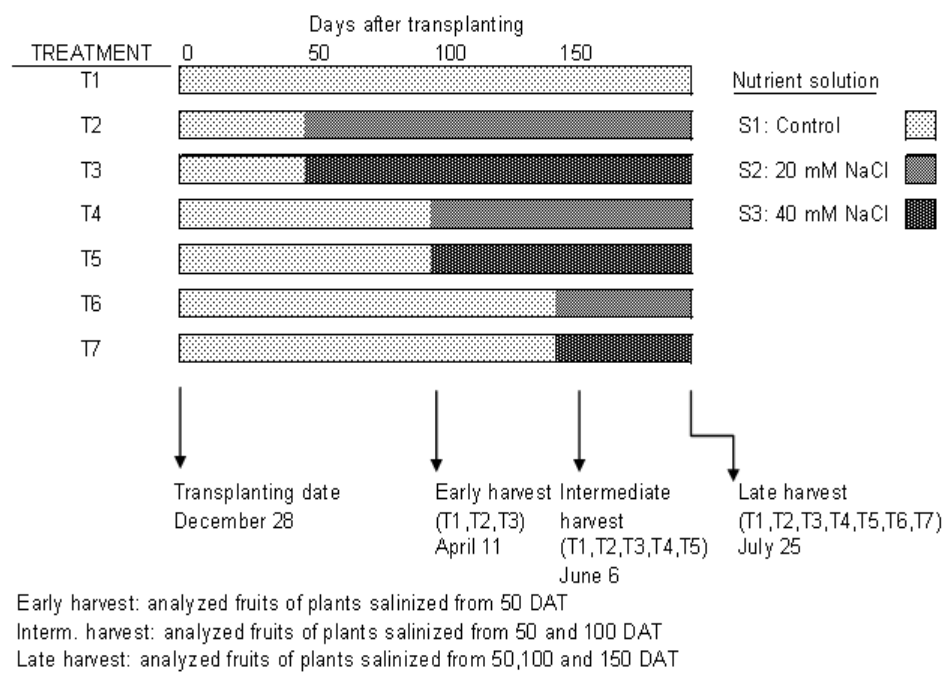

Figure 1. Experimental set up of pepper plants (Capsicum annuиm L., type Lamuyo) under different $\mathrm{NaCl}$ concentrations in the nutrient solution (S1, S2 and S3) applied to pepper plants beginning a given time after transplantation (DDT) (50, 100 and 150 days), giving 7 different treatments (T1-T7)

\subsection{Reagents}

Reagents were purchased from Sigma (Madrid, Spain) and used without purification. Triton X-114 was obtained from Fluka and was condensed three times as described by Bordier (1981) using $100 \mathrm{mM}$ sodium phosphate buffers ( $\mathrm{pH}$ 7.3). The detergent-rich phase of the third condensation had a concentration of $25 \% \mathrm{TX}-114(\mathrm{w} / \mathrm{v})$.

The hydrogen peroxide solutions were freshly prepared every day, and their concentrations were calculated using $\lambda_{240}=39.4 \mathrm{M}^{-1} \mathrm{~cm}^{-1}$ (Nelson \& Kiesow, 1972).

\subsection{Phenolic Compounds}

Phenolic compounds were determined in $80 \%$ ethanol using the Folin-Denis method (Kidron, Harel, \& Mayer, 1978). Analyses of each sample were made in triplicate, using chlorogenic acid for the quantification.

\subsection{HPLC Analysis of Ascorbic Acid (AA)}

A $50 \mathrm{~g}$ sample was homogenised with $100 \mathrm{~mL}$ of sodium phosphate buffer $(\mathrm{pH} 7.3)$ for $5 \mathrm{~min}$ in an Ultra Turrax (Ika, Staufen, Germany). The homogenate was filtered through four layers of cheesecloth. The sample was centrifuged at $1640 \times \mathrm{g}$ for $15 \mathrm{~min}$ at $20^{\circ} \mathrm{C}$. A sample was diluted $1: 1(\mathrm{v} / \mathrm{v})$ with $4.5 \%$ metaphosphoric acid and filtered through a $0.45-\mu \mathrm{m}$ filter prior to injection. AA concentrations were measured following Asami method, with some modifications (Asami, Hong, Barret, \& Mitchell, 2003).

Analysis was performed using an HPLC (Merck-Hitachi, Darmstad, Germany), in a reverse-phase column Lichrospher 100 RP-18 column (Merck, Darmstad, Germany) $(25 \times 0.4 \mathrm{~cm}, 5 \mu \mathrm{m}$ particle size) at $245 \mathrm{~nm}$ using a diode array detector Shimadzu SPD-M6A UV (Shimadzu, Kyoto, Japan). The mobile phase was nanopure water brought to $\mathrm{pH} 2.2$ with sulphuric acid and the flow rate was $0.5 \mathrm{~mL} \mathrm{~min}^{-1}$ (Asami et al. 2003).

All samples were run in triplicate and the linearity range was determined from 0.005 to $0.1 \mathrm{mg} / \mathrm{mL}$.

\subsection{ORAC-FL Assay}

The ORAC analyses were carried out on a Synergy HT multi-detection microplate reader, from Bio-Tek Instruments, Inc. (Winooski, Vt, USA), using 96-well polystyrene microplates with black sides and clear bottoms, purchased from Nalge Nunc International. Fluorescence was read through the clear bottom, with an excitation wavelength of $485 / 20 \mathrm{~nm}$ and an emission filter of $528 / 20 \mathrm{~nm}$. The plate reader was controlled by KC4, version 3.4, software. The oxygen radical absorbance capacity was determined as described by Dávalvos with slight modifications (Dávalvos, Gómez-Cordovés, \& Bartolomé, 2004). The reaction was carried out in $75 \mathrm{mM}$ sodium phosphate buffer ( $\mathrm{pH} 7.4)$, and the final reaction mixture was $200 \mu \mathrm{L} .100 \mu \mathrm{L}$ FL ( $3 \mathrm{nM}$, final concentration) and $70 \mu \mathrm{L}$ of the pepper extract were placed in the wells of the microplate. The mixture was preincubated for $30 \mathrm{~min}$ at $37{ }^{\circ} \mathrm{C}$, before rapidly adding the AAPH solution $(30 \mu \mathrm{L} ; 19 \mathrm{mM}$, final concentration) using a multichannel pipette. The microplate was immediately placed in the reader and the fluorescence recorded every $1.14 \mathrm{~min}$. for $120 \mathrm{~min}$. The microplate was automatically shaken prior to each reading. A blank with FL and AAPH using 
sodium phosphate buffer instead of the antioxidant solution and eight calibration solutions using Trolox C (6.25, $12.5,15,18.75,21.25,25,27.5$ and $31.25 \mu \mathrm{M}$ ) as antioxidant were also used in each assay. All reaction mixtures were prepared in triplicate and at least three independent assays were performed for each sample. In order to avoid a temperature effect, only the inner 60 wells were used for experimental purposes, while the outer wells were filled with $200 \mu \mathrm{L}$ of distilled water.

The results were expressed as relative fluorescence with respect to the initial reading. The area under the fluorescence decay curve (AUC) was calculated by the Equation (1):

$$
A U C=1+\frac{\sum_{i=114}^{i=120} f i}{f_{0}}
$$

where $f_{0}$ is the initial fluorescence reading at $0 \min$ and $f_{i}$ is the fluorescence reading at time $i$. The net AUC corresponding to the sample was calculated by subtracting the AUC corresponding to the blank. Data processing was performed using Sigmaplot software package (Jandel Scientific, German).

\subsection{Partial Purification of Pepper POD}

Pepper POD was extracted and partially purified using the method as described by our group (Serrano-Martínez et al., 2008). Fresh peppers were washed, and the seeds and peduncle were removed. A $50 \mathrm{~g}$ sample was homogenised with $100 \mathrm{~mL}$ of sodium phosphate buffer $(\mathrm{pH}$ 7.3) for $5 \mathrm{~min}$ in an Ultraturrax. The homogenate was filtered through four layers of cheesecloth and the filtrate was subjected to temperature-induced phase partitioning by adding TX-114 at $4{ }^{\circ} \mathrm{C}$ so that the final detergent concentration was $4 \%(\mathrm{w} / \mathrm{v})$. The mixture was kept at $4{ }^{\circ} \mathrm{C}$ for $15 \mathrm{~min}$ and then warmed to $35^{\circ} \mathrm{C}$ for $15 \mathrm{~min}$. At this time, the solution became spontaneously turbid due to the formation, aggregation and precipitation of large mixed micelles of detergent, which contained hydrophobic proteins and phenolic compounds. This turbid solution was centrifuged at $10,000 \times \mathrm{g}$ for $15 \mathrm{~min}$, at $25^{\circ} \mathrm{C}$. After discarding the pellet and detergent-rich phase, the clear detergent-poor supernatant which contained the soluble POD, was brought to $30 \%$ saturation with $\left(\mathrm{NH}_{4}\right)_{2} \mathrm{SO}_{4}$ under continuous stirring at $4{ }^{\circ} \mathrm{C}$. After one hour, the solution was centrifuged at $60,000 \mathrm{x} g$ for $30 \mathrm{~min}$ at $4{ }^{\circ} \mathrm{C}$ and the pellet was discarded. $\left(\mathrm{NH}_{4}\right)_{2} \mathrm{SO}_{4}$ was added to the clear supernatant to give $80 \%$ saturation and stirred for 1 hour at $4{ }^{\circ} \mathrm{C}$. The precipitate obtained between $30 \%$ and $80 \%$ was collected by centrifugation at the same rotor speed and dissolved in a minimum volume of $100 \mathrm{mM}$ sodium phosphate buffer, $\mathrm{pH}$ 7.3. The salt content was removed by dialysis and the enzyme was stored at $-20^{\circ} \mathrm{C}$.

\subsection{Enzymatic Activity}

The POD activity was followed spectrophotometrically in a Shimadzu model UV-1603 spectrophotometer at the absorption maximum of the ABTS radical cation, $414 \mathrm{~nm}\left(\lambda_{414}=31.1 \mathrm{mM}^{-1} \mathrm{~cm}^{-1}\right)$ (Rodríguez-López, Espín, Del Amor, Tudela, Martínez, Cerdá, \& García-Cánovas, 2000). One unit of enzyme was defined as the amount of enzyme that produced $1 \mu \mathrm{mol}$ of ABTS radical per minute.

The standard reaction medium at $25{ }^{\circ} \mathrm{C}$ contained $1 \mathrm{ng} / \mathrm{mL}$ of partially purified peroxidase, $50 \mathrm{mM}$ sodium citrate buffer ( $\mathrm{pH} 4.5$ ), $1 \mathrm{mM}$ ABTS, $6 \mathrm{mM} \mathrm{H}_{2} \mathrm{O}_{2}$ and tropolone $0.2 \mathrm{mM}$ in a final volume of $1 \mathrm{~mL}$.

\subsection{Marketable Yield}

Four blocks of six bags each were examined for marketable yield (72 plants) per treatment. Fruit harvesting was performed at the green stage of ripening. Marketable fruit yield was considered those Extra, I, II and III fruit class category, being defined as Extra: uniform color, good health state, square shape, and weight $>190 \mathrm{~g}$; class I: uniform color, good health state, non-square shape and weight $>225 \mathrm{~g}$; class II: uniform color, good health state, non-square shape and weight of $224-170 \mathrm{~g}$; class III: uniform color, good health state, non-square shape and weight of $100-170 \mathrm{~g}$.

\subsection{Statistical Analysis}

All data were analyzed for significant differences by one-way analysis of variance and Duncan's multiple range test at $\mathrm{P}<0.05$ using the Statgraphics Centurion Version 15 statistical package (StatPoint Technologies Inc., Warenton, VA).

\section{Results}

\subsection{Phenolic Compounds}

In the present paper, the effects of increasing $\mathrm{NaCl}$ concentrations on phenolic compounds were determined in mature fruits of plants stressed at different ages. As the $\mathrm{NaCl}$ concentration in the irrigation water increased from 0 to $40 \mathrm{mM}$ (Figure 2) the total phenolic compound content in pepper fruits also increased. This effect was 
observed in early, intermediate or late harvested fruits (Figure 2), but it was most pronounced in fruits harvested early, in which the total phenolic content increased 4 folds compared with the 2 and 1,8 fold increase recorded in intermediate and late harvested fruits. This effect can be explained by the fact that the early harvested pepper came from younger plants with a greater response capacity. The level of total phenolics for T2 and 50 DAT was slightly increased with the age of the plant. However, in all cases, the level of total phenolics for T3 and 50 DAT was the same $(516 \mathrm{mg} / 100 \mathrm{~g} \mathrm{FW})$ it was independent of the plant age, whereas in the case of the control (T1), the level of phenolics increased with the age of the plant (Figure 2).
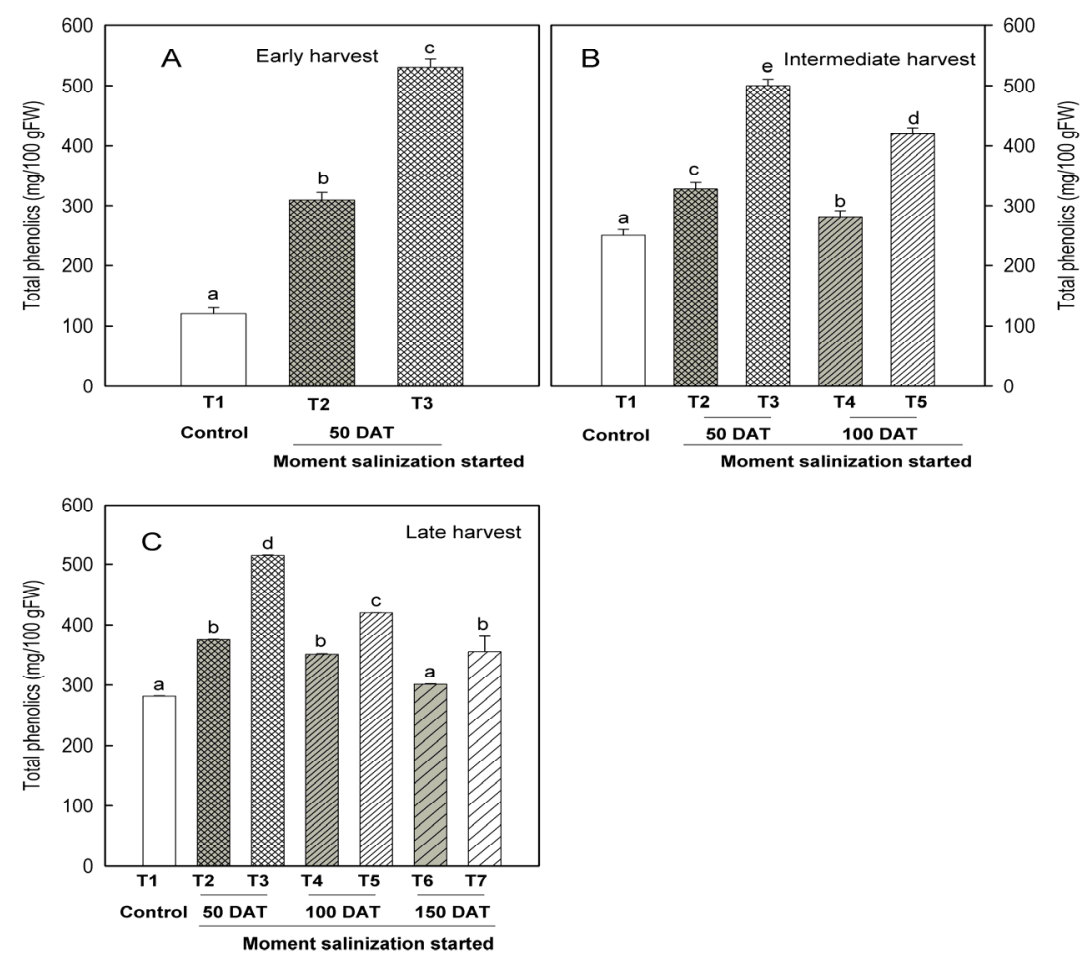

Figure 2. Effect of saline concentration in the irrigation water on the phenolic content of pepper fruits. (A) Early harvest, (B) Intermediate harvest and (C) Late harvest

\subsection{Ascorbic Acid (AA)}

When the vitamin $\mathrm{C}$ content was compared in mature pepper fruits from plants grown with different concentrations of $\mathrm{NaCl}$, the moment at which they were harvested was seen to have a very significant effect (Figure 3). In non-salinized plants (T1, Figure 3), early harvested plants produced mature fruits with much higher concentrations of vitamin $\mathrm{C}(440 \mathrm{mg} / 100 \mathrm{~g} \mathrm{FW})$ than fruits harvested later $(88$ and $31 \mathrm{mg} / 100 \mathrm{~g} \mathrm{FW})$ (Figure 3). Thus, older plants, produced mature pepper fruits with less vitamin C. $20 \mathrm{mM}$ of $\mathrm{NaCl}$ in the irrigated water significantly reduced the vitamin $\mathrm{C}$ content of early or intermediate harvested pepper fruits, but no further reduction was observed when $40 \mathrm{mM} \mathrm{NaCl}$ was applied.

In the case of early harvested peppers, T2 and T3 samples (treated with $\mathrm{NaCl} 20$ or $40 \mathrm{mM}$, respectively) showed a 35\% lower level of vitamin $\mathrm{C}$ that the control. In the case of intermediate harvested peppers, a $70 \%$ decrease was observed. However, in late harvested peppers a decrease only of $10 \%$ was observed (Figure 3 ).

It is also important to note that the time of treatment had no effect on the vitamin $\mathrm{C}$ level of mature fruits. Hence, the vitamin $\mathrm{C}$ level of peppers from 50, 100 or 150 DAT plants was the same (Figure 3). 

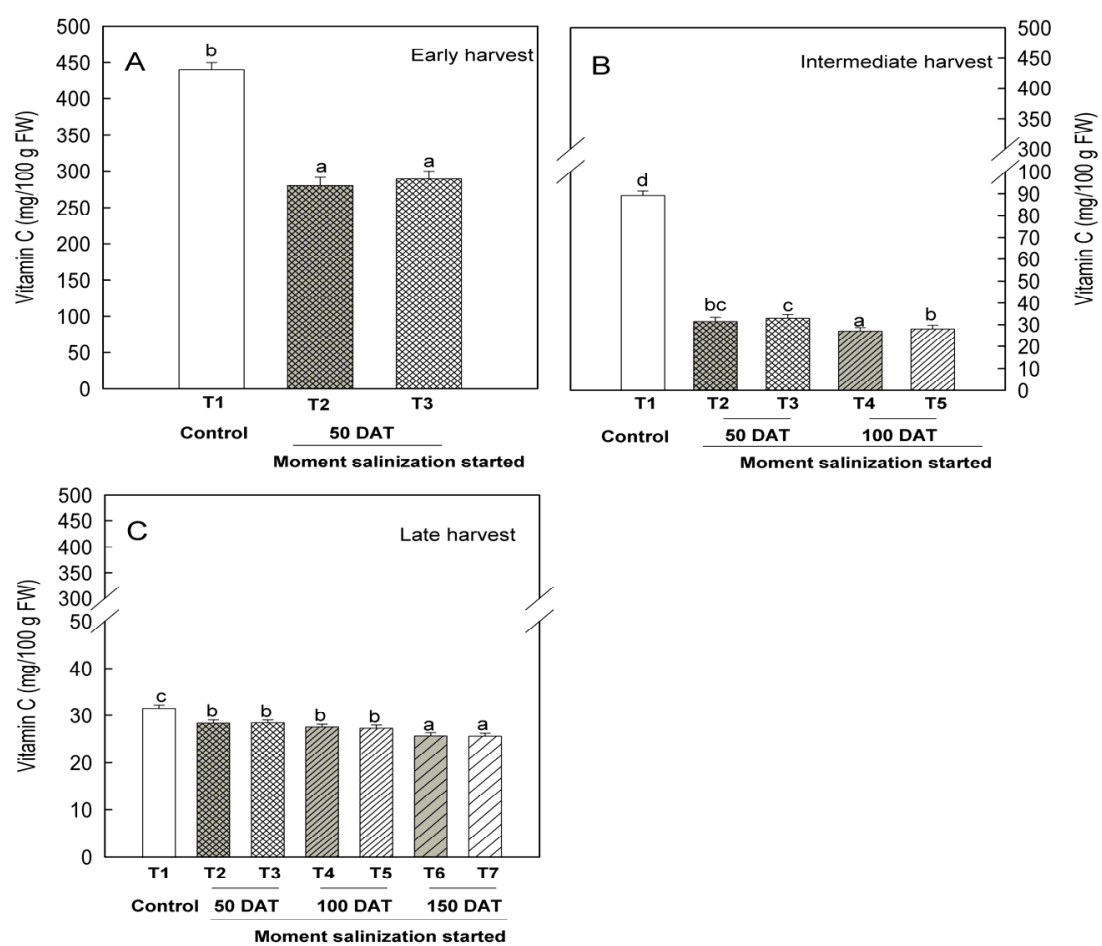

Figure 3. Effect of saline concentration in the irrigation water on Vitamin C content (mg/100 g FW) of pepper fruits. (A) Early harvest, (B) Intermediate harvest and (C) Late harvest

\subsection{Antioxidant Capacity}

When the antioxidant activity of mature pepper fruits from plants subjected to different $\mathrm{NaCl}$ concentrations was measured a slight but statistically important increase was observed when $20 \mathrm{mM} \mathrm{NaCl}$ was applied in the early stage of plant development (50 DAT, T2, T3) compared with the control (T1, Figure 4). However, in peppers from plants treated $100(\mathrm{~T} 4, \mathrm{~T} 5)$ or $150 \mathrm{DAT}(\mathrm{T} 6, \mathrm{~T} 7)$, antioxidant activity clearly decreased as salinity increased from 0 to $40 \mathrm{mM}$ (Figure 4). Thus, an application of 20 or $40 \mathrm{mM} \mathrm{NaCl}$ to old plants that had not previously been subjected to salt stress had more effect than observed in plants salinized since they were young (Figure 4). 

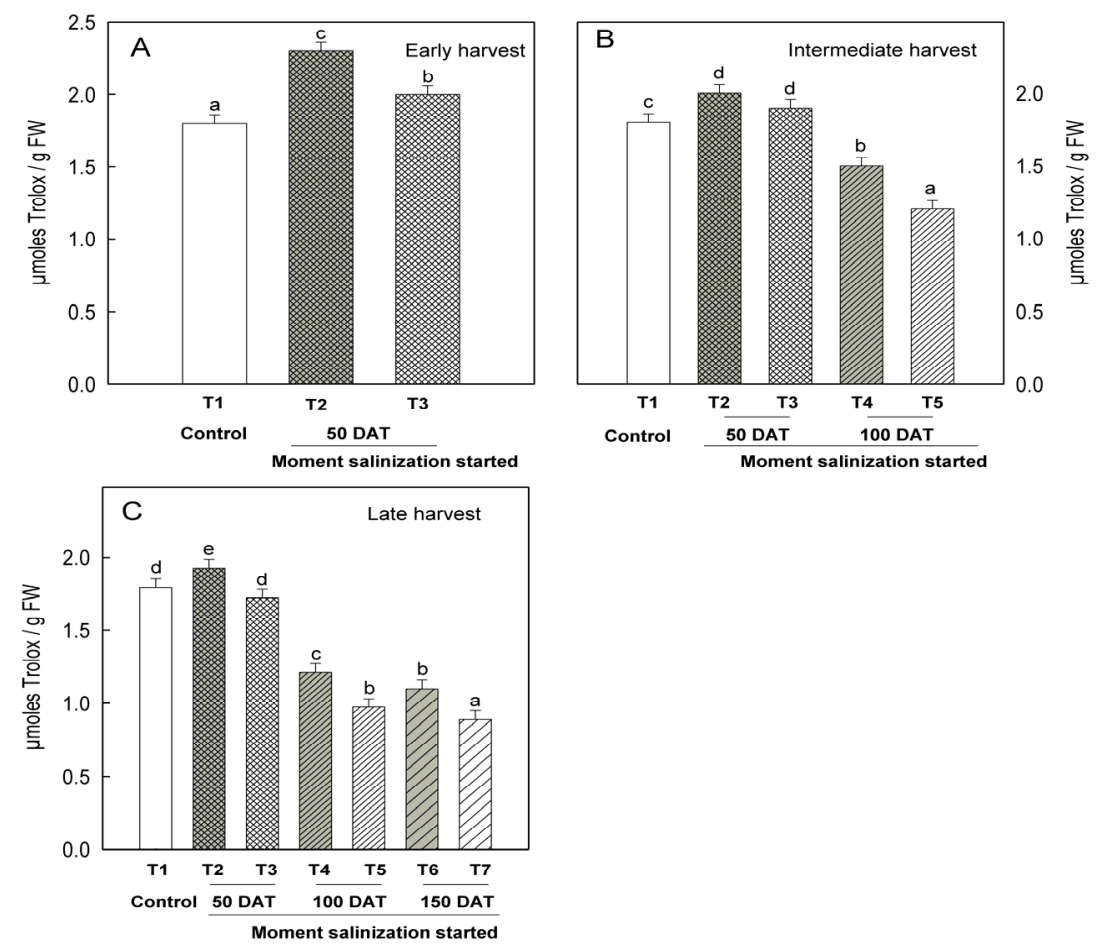

Figure 4. Effect of saline concentration in the irrigation water on antioxidant activity ( $\mu$ moles Trolox/g FW) of pepper fruits . (A) Early harvest, (B) Intermediate harvest and (C) Late harvest

\subsection{POD Activity}

The results obtained in this paper showed that the POD level increased in mature pepper fruits with the age of the plant. Thus, POD levels of 31, 161 and $200 \mathrm{UE} / \mathrm{g} \mathrm{FW}$ were recorded for early, intermediate or late harvested pepper fruits, respectively (T1, Figure 5). POD activity also increased with water salinity in pepper fruits harvested early, intermediate or late (Figure 5), an effect that was attenuated when salinity was imposed in the later stages of the crop cycle (T6, T7). When $40 \mathrm{mM} \mathrm{NaCl}$ was applied to the plant, late harvesting increased POD activity in mature pepper fruits, depending on the moment from which this concentration of $\mathrm{NaCl}$ was applied. For example POD activity was $200 \mathrm{EU} / \mathrm{g} \mathrm{FW}$ in control pepper fruits (T1) but 460, 380 and $320 \mathrm{EU} / \mathrm{g}$ FW in 50, 100 or 150 DAT fruits, respectively. 

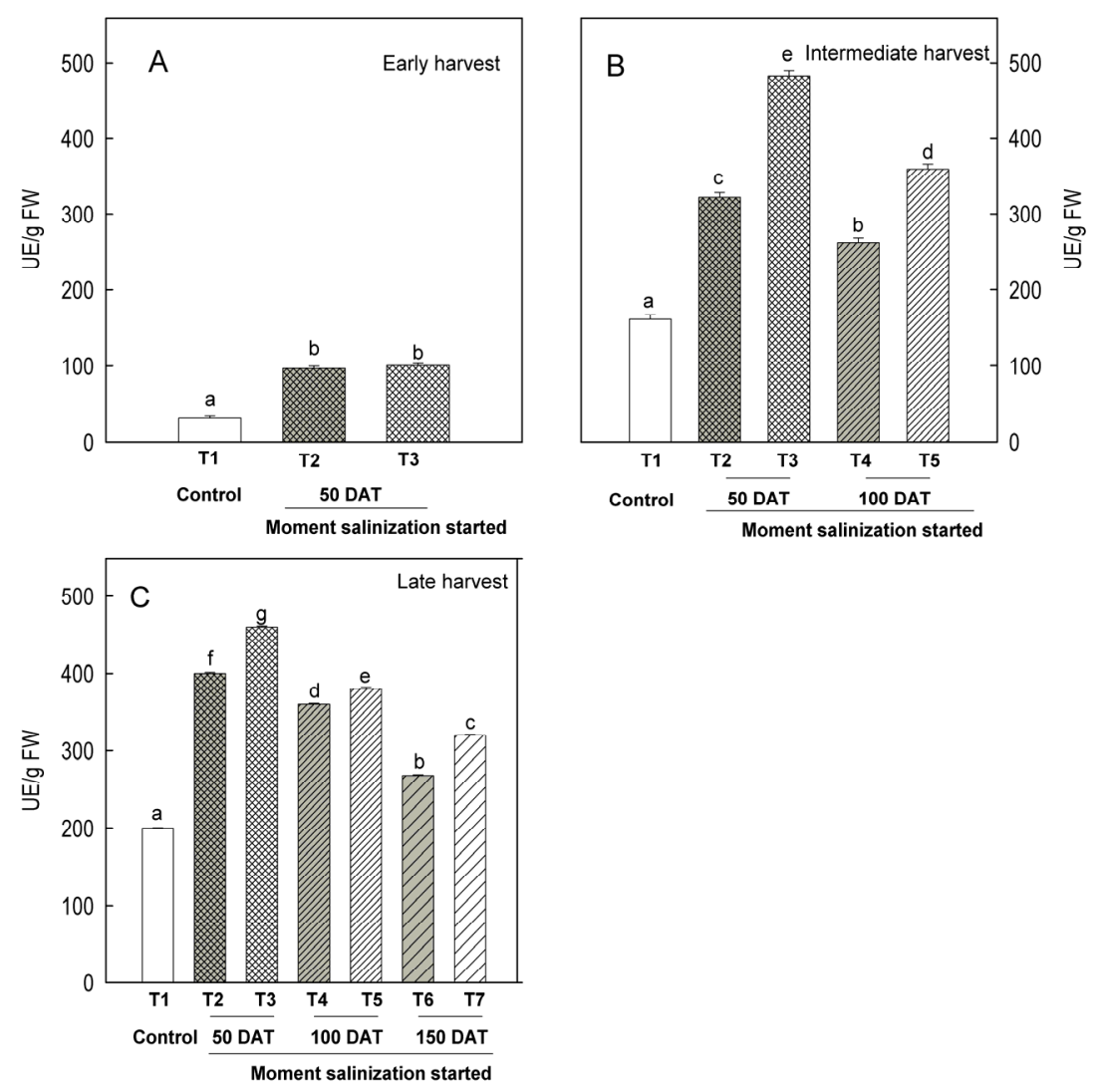

Figure 5. Effect of saline concentration of the irrigation water on POD activity of mature pepper fruits. (A) Early harvest, (B) Intermediate harvest and (C) Late harvest. The reaction medium at $25{ }^{\circ} \mathrm{C}$ contained $25 \mathrm{~mL}$ of POD extract, $1 \mathrm{mM} \mathrm{ABTS}, 6 \mathrm{mM} \mathrm{H}_{2} \mathrm{O}_{2}$ and $0.2 \mathrm{mM}$ Tropolone in $50 \mathrm{mM}$ citrate buffer $\mathrm{pH} 4.5$

\subsection{Marketable Fruit Yield}

Marketable fruit yield was significantly affected by both $\mathrm{NaCl}$ concentration in the nutrient solution and duration of the stress (Figure 6). Yield was increased as it was delayed the date stress was imposed and it was decreased as $\mathrm{NaCl}$ concentration increased. Thus, when $20 \mathrm{mM} \mathrm{NaCl}$ was applied from 50 DAT to the end of the study (T2), marketable yield was reduced by $55 \%$ but it was found a dramatic reduction (77\%) when $40 \mathrm{mM}$ of $\mathrm{NaCl}$ was applied during the same period (T3). Moreover, when it was delayed the application of the stress (150 DDT), marketable yield was significantly less affected compared to the control $(0 \mathrm{mM} \mathrm{NaCl})$ and it was found a decrease of $22.6 \%$ or $29 \%$ when 20 or $40 \mathrm{mM} \mathrm{NaCl}$ was applied (T6 y T7). 


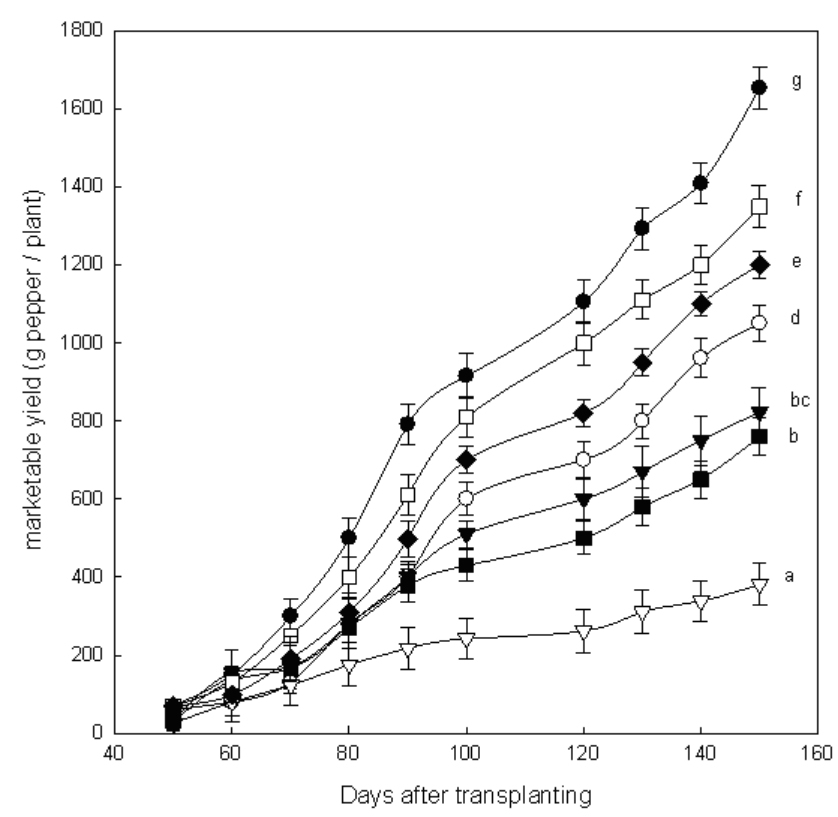

Figure 6. Effect of saline concentration of the irrigation water on marketable yield of sweet pepper. $(\bullet) \mathrm{T} 1: 0 \mathrm{mM}$

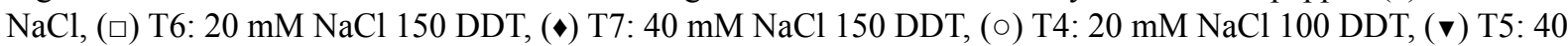
mM NaCl 100 DDT, (•) T2: 20 mM NaCl 50 DDT, ( $\nabla$ ) T3: 40 mM NaCl 50 DDT

\section{Discussion}

Phenolic compounds in plants are produced through the phenylpropanoid pathway, and can be induced by environmental stresses or elicitors (Giorgi, Mingozzi, Madeo, Speranza, \& Cocucci, 2009). Thus, the phenolic compounds in plants may be altered by salt stress, the growth conditions and plant genotype or variety.

It has been described in the literature that pepper cultivated in soilless conditions and moderate salinity is a good source of phenolic compounds, which, in addition to their antioxidant role, can contribute to improving fruit colour and flavour (Estrada, Bernal, Díaz, Pomar, \& Merino, 2002). The results obtained in this paper suggest that the increase in phenolic compounds concentration is directly related with the intensity of the stress (T2 and T3 of Figure 2) and also with the age of the plant (the phenolic content increased with age). Ruiz and Romero (2001) found that, terpenes and phenolics are the most important secondary metabolites for abiotic stress tolerance due to their structural properties, whilst Wahid and Ghazanfar (2006) found that the enhanced synthesis of soluble phenolics is directly correlated with salt tolerance. The phenolic compounds showed a higher response to salinity than that reported by Navarro et al. (2006), perhaps indicating the higher salinity tolerance of this variety.

The main form of vitamin $\mathrm{C}$ in pepper is AA, a form that contributes $95 \%$ of the total content of vitamin $\mathrm{C}$ (Marín, Ferreres, Tomás-Barberán, \& Gil, 2004). Vitamin C is highly bioavailable and it is consequently one of the most important water-soluble antioxidants in cells, efficiently scavenging reactive oxygen species such as $\mathrm{O}_{2}^{-}, \mathrm{OH}$, peroxyl radicals and singlet oxygen (Halliwell, 1996).

The relatively low impact of saline water on vitamin $\mathrm{C}$ synthesis in late harvested fruit could indicate that the moment of harvest is more important than the duration of saline stress.

Navarro et al. (2006) found that salinity reduced the vitamin C content of green peppers, while in cherry tomato, it has been reported that an increase in the salt stress level produces an increase in both vitamin $\mathrm{C}$ and $\mathrm{E}$ contents (Serio, De Gara, Caretto, Leo, \& Santamaría, 2004). Our results suggest that $20 \mathrm{mM} \mathrm{NaCl}$ in the irrigation water is sufficient to synthesize vitamin $\mathrm{C}$ in the fruits (Figure 3).

It has previously been described that pepper fruits subjected to hyperosmotic stress produce a physiological antioxidant response (Smirnoff, 1995). Very few studies have been carried out to evaluate the influence of saline stress on the antioxidant activity of fruit. The results obtained in this paper are similar to those described in the literature for tomato (D’Amico, Izzo, Navari-Izzo, Tognoni, \& Pardossi, 2003) and strawberry (Keutgen \& Pawelzik, 2007). The increase in antioxidant activity with water salinity of mature peppers from young plants, treated from 50 DAT (Figure 4) may be due to the greatly increased synthesis of phenolic compounds (Figure 1). 
Moreover, the decrease with water salinity of antioxidant activity of mature peppers from plants treated 100 and 150 DAT is probably due to a decrease in both phenolics (Figure 2) and vitamin C (Figure 3).

POD is an oxidative enzyme associated with many cellular alterations. It is known to catalyze the crosslinking between tyrosine residues of cell walls and ferulic acid (Fry, 1986). Moreover, a clear correlation between POD and the synthesis of lignin and suberin has been established (Lagrimini, Vaughn, Erb, \& Miller, 1993). An increase of POD in ripe cucumber, especially in the fruit skin has also been described (Repka \& Fischerrová, 1996). All these studies point to the involvement of POD in the changes that take place in the cell walls as the cells adapt to stress.

When the influence of salt stress in the POD activity was studied (Figure 5), the results obtained in this paper were similar to those described for Vinal (Prosopis ruscifolia G.), in which salt stress doubled POD activity compared with the control. It has also been described how the roots of a hydroponic crop of tomato (Lycopersicon esculentum cv. Pera) showed an increase in POD activity ten days after the salt stress was applied (Quiroga et al., 2000). In the same way, POD activity increased in melon fruit (Cucumis Melo L.) when plants were grown under salt stress (Rodríguez-López et al., 2000).

This increase in POD activity may be related with the increase in phenolic compounds (Figure 2) and antioxidant activity observed with increasing salinity in the irrigation water (Figure 4).

Several studies pointed out that fruit yield reduction under saline conditions was lower with decreasing time of salt exposure (Adams \& Ho, 1993; del Amor et al., 1999; Del Amor, Martínez, \& Cerdá, 2001). This could be related to the time during which high concentrations of $\mathrm{Cl}^{-}$and $\mathrm{Na}^{+}$remain in the leaves, but also associated with a nutrient umbalance caused by disturbed uptake or distribution of essential mineral nutrient as Chartzoulakis and Klapaki (2000) studied the response of two pepper hybrids during different growth stages (germination, seedling growth and vegetative growth) which agreed with our results about the differential response of this crop to salinity with respect to the stage at which salinity was imposed (Figure 6). Nowadays technological advances have made desalination an economically feasible solution for high-return agriculture, especially in arid regions but the relatively high cost of desalination are still prohibitively high for full use by most irrigated agriculture (Martínez Beltrán \& Koo-Oshima, 2006).

In conclusion, irrigation with saline water affected several parameters of pepper fruit quality: phenolic compounds, vitamin $\mathrm{C}$, antioxidant capacity and peroxidase activity. An increase in the $\mathrm{NaCl}$ concentration of the irrigation water led to a decrease in the vitamin $\mathrm{C}$ level in the late harvested pepper fruits, and in the antioxidant capacity. Total phenolics and peroxidase activity increased significantly as the saline concentration increased in water. Additionally, this study showed that the marketable fruit yield was significantly affected by the salinity in the nutrient solution and duration of stress. Therefore, this study shows the differential quality of fruits when they are harvested in the early or late stages of the crop cycle. The increase in salinity of the irrigation water led particularly increased the antioxidant activity in young plants. This study can provide a methodology to save good quality water by using an irrigation solution with moderate salinity at the appropriate growth stage in sweet pepper crop. This is very important for the growers and this also shows the need of the study commercially.

\section{Acknowledgements}

This research has been supported by Fundation Seneca (Agencia Regional de Ciencia y Tecnología, Región de Murcia) under project PFE-SENECA/06/10.

\section{References}

Adams, P., \& Ho, L. C. (1993). Effects of constant and fluctuating salinity on the yield, quality and calcium status of tomatoes. Journal of Horticultural Science \& Biotechnology, 64, 725-732.

Asami, D. K., Hong, Y. J., Barret, D. M., \& Mitchell, A. E. (2003). Comparison of the total phenolic and ascorbic acid content of freeze-dried and air-dried marionberry, strawberry, and corn grown using conventional, organic, and sustainable agricultural practices. Journal of Agricultural and Food Chemistry, 51, 1237-1241. http://dx.doi.org/10.1021/jf020635c

Bordier, C. (1981). Phase separation of integral membrane proteins in Triton X-114 solution. Journal of Biological Chemistry, 256, 1604-1607.

Bramley, P. M. (2000). Is lycopene beneficial to human health? Phytochemistry, 54, $233-236$. http://dx.doi.org/10.1016/S0031-9422(00)00103-5

Chartzoulaki, S. K., \& Klapaki, G. (2000). Response of two greenhouse pepper hybrids to $\mathrm{NaCl}$ salinity during 
different growth $\quad$ stages. Scientia $\quad$ Horticulturae, $\quad 86, \quad 247-260$. http://dx.doi.org/10.1016/S0304-4238(00)00151-5

D’Amico, M. L., Izzo, R., Navari-Izzo, F., Tognoni, F., \& Pardossi, A. (2003). See water irrigation; antioxidants and quality of tomato berries (Lycopersicon esculentum Mill.). Acta Horticulturae, 609, 59 -65.

Dávalvos, A., Gómez-Cordovés, C., \& Bartolomé, B. (2004). Extending applicability of the oxigen radical absorbance capacity (ORAC-Fluorescein) assay. Journal of Biological Chemistry, 52, 48-54.

Del Amor, F. M., Martínez, V., \& Cerdá, A. (1999). Salinity duration and concentration affect fruit yield and quality, and growth and mineral composition of melon plants grown in perlite. HortScience, 34, 1234-1237.

Del Amor, F. M., Martínez, V., \& Cerdá, A. (2001). Salt tolerance of tomato plants as affected by stage of plant development. HortScience, 36, 1260-1263.

Del Amor, F. M., \& Gómez-López, M. D. (2009). Agronomical response and water use efficiency of sweet pepper plants grown in different greenhouse substrates. HortScience, 44, 810-814.

Estrada, B., Bernal, M. A., Díaz, J., Pomar, F., \& Merino, F. (2002). Capsaicinoids in vegetative organs of Capsicum annuum L. in relation to fruiting. Journal of Horticultural Science \& Biotechnology, 50, 1188-1191.

Foyer, C. H. (1993). Ascorbic acid. In R. G. Alscher \& J. L. Hess (Eds.), Antioxidants in higher plants (pp. 51-58). Boca Raton: CRC Press.

Fry, S. C. (1986). Cross-linking of matrix polymers in the growing cell walls of angiosperms. Annual Review of Plant Physiology, 37, 165-186. http://dx.doi.org/10.1146/annurev.pp.37.060186.001121

Giorgi, A., Mingozzi, M., Madeo, M., Speranza, G., \& Cocucci, M. (2009). Effect of nitrogen starvation on the phenolic metabolism and antioxidant properties of yarrow (Achillea collina Becker ex Rchb.). Food Chemistry, 114, 204-211. http://dx.doi.org/10.1016/j.foodchem.2008.09.039

HalliwelL, B. (1996). Vitamin C: antioxidant or pro-oxidant in vivo? Free Radical Research, 25, $439-454$. http://dx.doi.org/10.3109/10715769609149066

Harris, J. R. (1996). Subcellular Biochemistry. Ascorbic acid: Biochemistry and biomedical cell biology (Vol. 25). Plenum, New York. http://dx.doi.org/10.1007/978-1-4613-0325-1

Howard, R. L., Talcott, S. T., Brenes, C. H., \& Villalon, B. (2000). Changes in phytochemical and antioxidant activity of selected pepper cultivars (Capsicum species) as influenced by maturity. Journal of Agricultural and Food, 48, 1713-1720. http://dx.doi.org/10.1021/jf990916t

Jovicich, E., Cantliff, D. J., Sargent, S. A., \& Osborne, L. S. (2004). Production of greenhouse-grown peppers in Florida. Florida Cooperative Extension Service publication HS979. Retrieved from http://www.hos.ufl.edu/ProtectedAg/EDIS/HS22800.pdf

Keutgen, A. J., \& Pawelzik, E. (2007). Modifications of Strawberry Fruit Antioxidant Pools and Fruit Quality under $\mathrm{NaCl}$ Stress. Journal of Agricultural and Food Chemistry, 55, 4066-4072. http://dx.doi.org/10.1021/jf070010k

Kidron, M., Harel, M., \& Mayer, A. M. (1978). Catechol oxidase activity in grapes and wine. American Journal of Enology and Viticulturae, 219, 30-35.

Lagrimini, L. M., Vaughn, J., Erb, W. A., \& Miller, A. S. (1993). Peroxidase overproduction in tomato: Wound-induced polyphenol deposition and disease resistance. HortScience, 28, 218-221.

Marín, A., Ferreres, F., Tomás-Barberán, F. A., \& Gil, M. I. (2004). Characterization and quantification of antioxidant constituents of sweet pepper (Capsicum annuum L.). Journal of Agricultural and Food Chemistry, 52, 3861-3869. http://dx.doi.org/10.1021/jf0497915

Martínez-Beltran, J., \& Koo-Oshima, S. (2006). FAO Expert Consultation on Water Desalination for Agricultural Applications, Rome (Italy). 26-27 Apr 2004/FAO, Rome (Italy). FAO Land and Water Discussion Paper (No. 5); Land and Water Development Div. (p. 48).

Morales-García, D., Stewart, K. A., Seguin, P., \& Madramootoo, C. (2011). Supplemental saline drip irrigation applied at different growth stages of two bell pepper cultivars grown with or without mulch in non-saline soil. Agricultural Water Management, 98, 893 - 898. http://dx.doi.org/10.1016/j.agwat.2010.11.012

Munns, R., \& Termaat, A. (1986). Whole-Plant Responses to Salinity. Australian Journal of Plant Physiology, 13, 143-160. http://dx.doi.org/10.1071/PP9860143 
Munns, R. (2002). Comparative physiology of salt and water stress. Plant, Cell \& Environment, 25, 239-250. http://dx.doi.org/10.1046/j.0016-8025.2001.00808.x

Namiki, M. (1990). Antioxidants/antimutagens in food. CRC Critical Reviews in Food Science and Nutrition, 29, 273-300. http://dx.doi.org/10.1080/10408399009527528

Navarro, J. M., Garrido, C., Carvajal, M., \& Martínez, V. (2002). Yield and fruit quality of pepper plants under sulphate and chloride salinity. Journal of Horticultural Science \& Biotechnology, 77, 52-57.

Navarro, J. M., Flores, P., Garrido, C., \& Martínez, V. (2006). Changes in the contents of antioxidant compounds in pepper fruits at different ripening stages, as affected by salinity. Food Chemistry, 96, 66-73. http://dx.doi.org/10.1016/j.foodchem.2005.01.057

Nelson, D. P., \& Kiesow, L. A. (1972). Enthalpy of decomposition of hydrogen peroxide by catalase at 25 degrees $\mathrm{C}$ (with molar extinction coefficients of $\mathrm{H}_{2} \mathrm{O}_{2}$ solutions in the UV). Analytical Biochemistry, 49, 474-478. http://dx.doi.org/10.1016/0003-2697(72)90451-4

Parida, A. K., \& Das, A. B. (2005). Salt tolerance and salinity effects on plants: a review. Ecotoxicology and Environmental Safety, 60, 324-349. http://dx.doi.org/10.1016/j.ecoenv.2004.06.010

Price, S. F., Breen, P. J., Valladao, M., \& Watson, B. T. (1995). Cluster sun exposure and quercetin in Pinot noir grapes and wine. American Journal of Enology and Viticulturae, 46, 187-194.

Quiroga, M., Guerrero, C., Botella, M. A., Barcel, A., Amaya, I., Medina, M. I., ... Valpuesta, V. A. (2000). Tomato peroxidase envolved in the shyntesis flignin and suberin. Plant Physiology, 122, 1119-1127. http://dx.doi.org/10.1104/pp.122.4.1119

Rengasamy, P. (2002). Transient salinity and subsoil constraints to dryland farming in Australian sodic soils: an overview. Australian Journal of Experimental Agriculturae, 42, 351-361. http://dx.doi.org/10.1071/EA01111

Repka, V., \& Fischerrová, I. (1996). Distribution of the stress-related anionic peroxidases in different cucumber organs. Plant Biology, 38, 571-583. http://dx.doi.org/10.1007/BF02890609

Richard-Forget, F. C., \& Gauillard, F. A. (1997). Oxidation of chlorogenic acid, catechins and 4-methylcatechol in model solutions by combinations of pear (Pyrus communis cv. Williams) polyphenol oxidase and peroxidase: A possible involvement of peroxidase in enzymatic browning. Journal of Agricultural and Food Chemistry, 45, 2472-2476. http://dx.doi.org/10.1021/jf970042f

Robinson, D. S. (1991). Peroxidase and catalase. In D. S. Robinson \& N. A. M. Eskin (Eds.), Oxidative enzymes in foods (pp. 1-49). New York: Elsevier Press.

Rodríguez-López, J. N., Espín, J. C., Del Amor, F., Tudela, J., Martínez, V., Cerdá, A., \& García-Cánovas, F. (2000). Purification and Kinetic Characterization of an Anionic Peroxidase from Melon (Cucumis Melo L.) Cultivated under Different Salinity Conditions. Journal of Agricultural and Food Chemistry, 48, 1537-1541. http://dx.doi.org/10.1021/jf9905774

Ruiz, J. M., \& Romero, L. (2001). Bioactivity of the phenolic compounds in higher plants. Studies in Natural Products Chemistry, 25, 651-681. http://dx.doi.org/10.1016/S1572-5995(01)80020-X

Serio, F., De Gara, L., Caretto, S., Leo, L., \& Santamaría, P. (2004). Influence of an increased $\mathrm{NaCl}$ concentration on yield and quality of cherry tomato grown in posidonia (Posidonia oceanica (L.) Delile). Journal of the Science of Food and Agriculturae, 84, 1885-1890. http://dx.doi.org/10.1002/jsfa.1883

Serrano-Martínez, A., Fortea, M. I., Del Amor, F. M., \& Núñez-Delicado, E. (2008). Kinetic characterization and thermal inactivation study of partially purified red pepper (Capsicum annuиm L.) Peroxidase. Food Chemistry, 107, 193-199. http://dx.doi.org/10.1016/j.foodchem.2007.08.028

Smirnoff, N. (1995). Antioxidant Systems and plant response to the environment. In N. Smirnoff (Eds.), Environment and plant metabolism: Flexibility and acclimation (pp. 217-243). Oxford: BIOS Scientific Publisher Ltd.

Tomás-Barberán, F. A., \& Espín, J. C. (2001). Phenolic compounds and related enzymes of quality in fruit and vegetables. Journal of the Science of Food and Agriculturae, 81, 853-876. http://dx.doi.org/10.1002/jsfa.885

Wahid, A., \& Ghazanfar, A. (2006). Possible involvement of some secondary metabolites in salt tolerance of sugarcane. Journal of Plant Physiology, 163, 723-730. http://dx.doi.org/10.1016/j.jplph.2005.07.007 
Zhu, J. K. (2002). Salt and drought stress signal transduction in plants. Annual Review of Plant Physiology, 53, 247-273.

\section{Copyrights}

Copyright for this article is retained by the author(s), with first publication rights granted to the journal.

This is an open-access article distributed under the terms and conditions of the Creative Commons Attribution license (http://creativecommons.org/licenses/by/3.0/). 